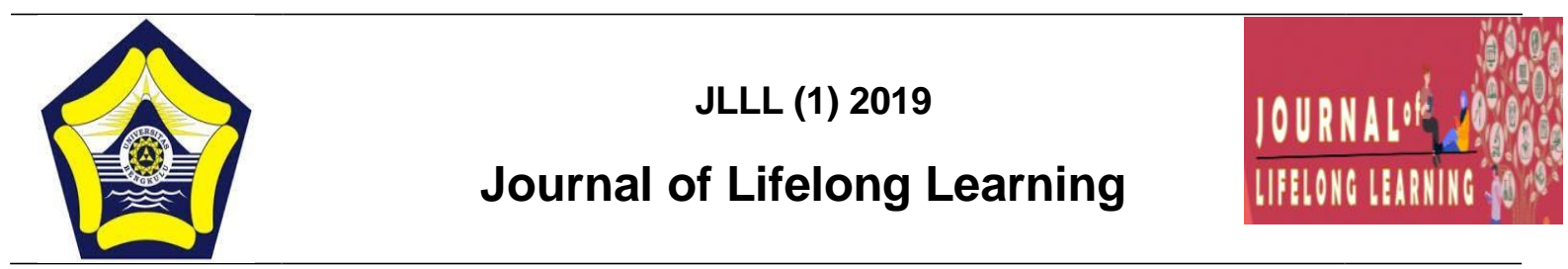

\title{
PENGELOLAAN KEGIATAN BELAJAR MASYARAKAT (PKBM) \\ DI KOTA BENGKULU \\ (Studi Pada PKBM Sriwijaya Sawah Lebar Kota Bengkulu)
}

\author{
Muhammad Nursamsi ${ }^{1}$, Riskan², ${ }^{2}$ arlan ${ }^{3}$
}

${ }_{1}^{1}$ Nonformal Education, University of Bengkulu, Indonesia, syamsimuhamad4@gmail.com

${ }^{2}$ Nonformal Education, University of Bengkulu, Indonesia, alazarbengkulu5015@gmail.com

${ }^{3}$ Nonformal Education, University of Bengkulu, Indonesia, parlanunib@gmail.com

\begin{abstract}
The purpose in this research are to know about planning, how to organize, how to realization and doing control from centre of society learning activity ( pusat kegiatan belajar masyarakat ) Sriwijaya. In this research use method qualitative with technique of collection the data are interview, observation and documentation. The subject has been choose is managment of PKBM Sriwijaya, there are consists of the leader is Mr. Ralin MS Gumay and the treasurer Mrs. Umi Yanti. To proving the validity of data, the researcher do to checking the data with triangulation, there are triangulation source, triangulation technique, and triangulation of time. The data has been analyze with 3 step, there are, reduction of data, presentation of data, and last is take a conclusion. The result from this research are found, first is planning, formulate the perspective and mission, prepare the tools and labor done in preparation. Second, how to organize, PKBM sriwijaya have management organization there are consists of builder, leader, secretary, and treasurer. Third is realization, in doing program activity, PKBM Sriwijaya use fund by society, and the curriculm they are use is from the goverment. Fourth, for doing control from manager of PKBM Sriwijaya, its about direct or not, the manager too, doing the controling the tutor will be become an object of evaluation.
\end{abstract}

Key words : Managment, Centre of society learning activity

(c) 2019 Dept of Nonformal Education UNIB

Address correspondence:

e-ISSN

JI. W.R. Supratman, Kandang Limun, Muara Bangka Hulu,

Kota Bengkulu, Bengkulu 38371 


\section{PENDAHULUAN}

Tidak bisa dipungkiri bahwa pendidikan adalah hal yang sangat penting dalam upaya meningkatkan Sumber Daya Manusia (SDM) ditengah masyarakat indonesia yang sedang membangun, khususnya dikota Bengkulu. Untuk melaksanakan pendidikan ini lembaga pendidikan formal tentunya sangat tidak mungkin untuk menjangkau semua lapisan masyarakat, terlebih lagi adanya faktor-faktor hambatan dari masyarakat seperti kemiskinan sehingga tidak menyanggupi mereka untuk bersekolah di pendidikan formal pada umumnya. Maka PKBM Sriwijaya sawah lebar kota Bengkulu merencanakan pendidikan non formal (PNF) untuk berbagai macam tingkatan terutama diperuntukkan bagi masyarakat yang kurang beruntung yang bertujuan untuk memberikan kesempatan bagi masyarakat dalam mendapatkan pendidikan yang layak terutama bagi anak-anak yang putus sekolah dan masyarakat luas pada umumnya. PKBM Sriwijaya memiliki berberapa program diantaranya pendidikan kesetaraan, pendidikan anak usia dini, kursus bahasa korea dan bahasa inggris dan bimbel. Semua program yang diselenggarakan PKBM Sriwijaya semata mata bertujuan untuk memajukan masyarakat sekitar dan pengelola tidak mementingkan kebutuhan pribadinya tujuannya hanya satu yaitu memberantas kebodohan. Dengan adanya PKBM Sriwijaya ini pengelola berharap bisa membantu masyarakat untuk mengatasi permasalahan dalam kehidupannya, seperti masalah pendidikan, perekonomian, dan lain sebagainya.

Pengelola merupakan salah satu faktor penting dalam pembelajaran. Kegiatan pembelajaran tidak akan bisa berjalan tanpa ada keikutsertaannya dalam kegiatan proses belajar mengajar yang diakukan. Karena pengelola merupakan komponen yang paling berpengaruh akan terciptanya proses dan hasil pendidikan yang berkualitas pada semua jenjang dan satuan pendidikan disamping unsur-unsur pendidikan lainnya. Sebagai institusi yang didirikan oleh, dari dan untuk masyarakat, PKBM memiliki potensi sebagai institusi yang mandiri. Meskipun awal berdirinya banyak PKBM yang bergantung pada bantuan.dan dana dari pemerintah, dalam jangka panjang diharapkan pada sebagian besar PKBM akan tumbuh kemandirian, dalam hal ini peran dominan pemerintah yang selama ini menjadi semakin berkurang dan lebih pada peran fasilitasi akan dapat berjalan seiring dengan kemandirian PKBM.

Berdasarkan survey penulis dari beberapa PKBM seperti PKBM Ilmu Bunda, PKBM Tabah dan PKBM Mata Pena, PKBM Sriwijaya melakukan proses pembelajaran pada pendidikan kesetaraan dan mempunyai warga belajar yang terus bertambah dari tahun ketahun dibanding PKBM yang lainya. Salah satu penyebabnya adalah timbulnya kesadaran masyarakat akan pentingnya pendidikan, juga adanya pengelolaan program-program yang sangat baik. Dari hal inilah penulis tertarik untuk mengetahui bagaimanakah manajemen PKBM Sriwijaya sawah lebar kota Bengkulu.Dilihat dari latar belakang masalah maka permasalahan umum yang diangkat dalam penelitian ini Manajemen PKBM di Kota Bengkulu (studi pada PKBM sriwijaya sawah lebar kota bengkulu)".

\section{Metode}

Metode penelitian yang digunakan pada penelitian ini adalah metode kualitatif. Danim (2002:41) yang mengemukakan ciri-ciri dominan penelitian deskritif sebagai berikut: 1) bersifat mendeskripsikan kejadian atau peristiwa yang bersifat faktual, 2) dilakukan secara survey, 3) bersifat mencari informasi dan dilakukan secara mendetail, 4) mengidentifikasi masalah untuk mendapatkan justifikasi keadaan dan praktik yang sedang berlangsung, 5) mendeskripsikan subjek yang sedang dikelola oleh kelompok tertentu. 


\section{HASIL DAN PEMBAHASAN}

Sesuai dengan permasalahan, tujuan penelitian dan pembahasan, maka dapat disimpulkan bahwa permasalahan yang dihadapi pusat kegiatan belajar masyarakat (PKBM) Sriwijaya dalam manajemen pusat kegiatan belajar masyarakat (PKBM) di kota Bengkulu adalah sebagai berikut:

1. Perencanaan yang dilakukan oleh pengelola PKBM Sriwijaya yaitu, menyusun perencanaan awal dari setiap program yang akan dilaksanakan, merumuskan tujuan dari pendirian lembaga, merumuskan visi dan misi serta mempersiapkan sarana dan prasarana yang akan digunakan dalam melaksanakan program kerja. Yang terlibat dalam perencanaan ini adalah semua pengelola pusat kegiatan belajar masyarakat (PKBM) Sriwijaya kota Bengkulu.

2. Pengorganisasian pusat kegiatan belajar masyarakat (PKBM) Sriwijaya yang terdiri dari Pembina Yayasan : Ka. Subdin PAUDNI, Ketua PKBM : Ralin MS Gumay S.AP, Sekretaris: U. Yanti, dan Bendahara :Hermanto, hingga warga belajar. Pengelola PKBM Sriwijaya telah membagi tugas dari setiap bidang organisasi yang tercantum dalam buku Tugas Pokok dan Fungsi (TUPOKSI) pengelola PKBM Sriwijaya sawah lebar kota Bengkulu.

3. Pelaksanaan: dalam melaksanakan program kerja yang sudah disusun di awal Pusat Kegiatan Belajar Masyarakat (PKBM) Sriwijaya menggunakan dana yang berasal dari suahdana (uang pendaftaran warga belajar), dan bantuan pemerintah, kurikulum yang digunakan pada program kesetaraan adalah kurikulum yang disusun oleh dinas pendidikan, kurikulum Pendidikan Anak Usia Dini menggunakan kurikulum yang disusun oleh pengelola PKBM Srriwijaya.

4. Pengawasan yang dilakukan oleh pengelola PKBM Sriwijaya yaitu pengawasan secara langsung, baik itu pada saat proses pembelajaran maupun di luar proses pembelajaran, pengelola juga mengontrol prilaku tutor dalam hal keteladanan kepada warga belajar yang dijadikan sebagai bahan evaluasi.

\section{PENUTUP}

\section{KESIMPULAN}

Sesuai dengan permasalahan, tujuan penelitian dan pembahasan, maka dapat disimpulkan bahwa permasalahan yang dihadapi pusat kegiatan belajar masyarakat (PKBM) Sriwijaya dalam manajemen pusat kegiatan belajar masyarakat (PKBM) di kota Bengkulu adalah sebagai berikut:

1. Perencanaan yang dilakukan oleh pengelola PKBM Sriwijaya yaitu, menyusun perencanaan awal dari setiap program yang akan dilaksanakan, merumuskan tujuan dari pendirian lembaga, merumuskan visi dan misi serta mempersiapkan sarana dan prasarana yang akan digunakan dalam melaksanakan program kerja. Yang terlibat dalam perencanaan ini adalah semua pengelola pusat kegiatan belajar masyarakat (PKBM) Sriwijaya kota Bengkulu.

2. Pengorganisasian pusat kegiatan belajar masyarakat (PKBM) Sriwijaya yang terdiri dari Pembina Yayasan : Ka. Subdin PAUDNI, Ketua PKBM : Ralin MS Gumay S.AP, Sekretaris: U. Yanti, dan Bendahara :Hermanto, hingga warga belajar. Pengelola PKBM Sriwijaya telah membagi tugas dari setiap bidang organisasi yang tercantum dalam buku Tugas Pokok dan Fungsi (TUPOKSI) pengelola PKBM Sriwijaya sawah lebar kota Bengkulu.

3. Pelaksanaan: dalam melaksanakan program kerja yang sudah disusun di awal Pusat Kegiatan Belajar Masyarakat (PKBM) Sriwijaya menggunakan dana yang berasal dari suahdana (uang pendaftaran warga belajar), dan bantuan pemerintah, kurikulum yang 
digunakan pada program kesetaraan adalah kurikulum yang disusun oleh dinas pendidikan, kurikulum Pendidikan Anak Usia Dini menggunakan kurikulum yang disusun oleh pengelola PKBM Srriwijaya.

4. Pengawasan yang dilakukan oleh pengelola PKBM Sriwijaya yaitu pengawasan secara langsung, baik itu pada saat proses pembelajaran maupun di luar proses pembelajaran, pengelola juga mengontrol prilaku tutor dalam hal keteladanan kepada warga belajar yang dijadikan sebagai bahan evaluasi.

\section{REFERENSI}

Arikunto, Suharsimi. 1998. Metode Penelitian Kualitatif dan Kuantitatif. Jakarta: PT Rineka Cipta

Denim Sudarwan 2002. Inovasi pendidikan : Dalam upaya peningkatan profesionalisme tenaga pendidik. Cetakan pertama. Bandung: CV Pustaka setia. Depdiknas.2003.Undang-Undang No. 20 Tahun 2003 Tentang Sistem Pendidikan Nasional. Jakarta: Dirjen Didasmen.

Fakultas Ilmu Pendidikan Universitas Negeri Yogyakarta.Balai Pengembangan Kegiatan Belajar.2001.Pengelolaan PKBM. Jakarta: Dirjen Pendidikan Luar Sekolah Kamil Mustofa (2011) Pendidikan Non formal pengembangan melalui pusat kegiatan belajar masyarakat (PKBM) di Indonesia ( sebuah pembelajaran dan kominka jepang). Bandung

Kamil Mustofa. 20009 Pendidikan Non formal pengembangan melalui pusat kegiatan belajar masyarakat. Bandung

Kementrian Pendidikan dan Kebudayaan. 2012. Standar dan prosedur penyelenggaraan pusat kegiatan belajar masyarakat (PKBM)

Lexy J. Moleong. 1995. Metodologi penelitian kualitatif. Bandung : PT. Remaja Rosdakarya. Bandung.

Mulyono.2011.Inovasi Pengelolaan Pusat Kegiatan Belajar Masyarak $\quad$ (PKBM).Bengkulu: Universitas Bengkulu

PP No.19 tahun 2005 tentang Standar Nasional Pendidikan

Rohidi, 1992. Metode Penelitian Kualitatif. Remaja Rosdakarya. Bandung

Simamora, Henry, 2004. Manajemen sumber daya manusia, Edisi ketiga, cetakan pertama, bagian penerbitan STIE YKPN, Yogyakarta.

Sudjana. 2008. Evaluasi program pendidikan luar sekolah. Bandung. PT Remaja Rosdakarya. Suratman, Asep 2008 Pedoman Penulisan Karya Ilmiah. FKIP Universitas Bengkulu. Sudjana, Djudju. 2010. Manajemen Program Pendidikan untuk Pendipdikan Non Formal dan Pengembangan Sumber Daya Manusia. Bandung: Falah Production Sugiono. 2010. Metode Penelitian Kuantitatif kualitatif dan $R \& D$. Bandung: $\quad$ Alfabet Sihombing, Umberto. 1999. Pendidikan Luar Sekolah: Kini dan Masa Depan. Jakarta: $\quad$ PD. Mahkota.

Sihombing, Umbertus. 2000. Pendidikan Luar Sekolah, Manajemen Strategi: $\quad$ Konsep, Kiat dan Pelaksanaan. Jakarta: PD. Mahkota. 
Stoner James,A.F. 1996. Manajemen, Edisi Bahasa Indonesia. Jakarta: $\quad$ PT.Prenhallindo. Terry, George R. 1984 Asas-asas manajemen. Bandung: PT Alumni Yulaelawati, 2012. Efektivitas pengelolaan pusat kegiatan belajar masyarakat.

(Skripsi). Pendidikan Luar Sekolah. Universitas Pendidikan Indonesia. Bandung 